\title{
The community of hummingbirds (Aves: Trochilidae) and the assemblage of flowers in a Caatinga vegetation
}

\author{
Las-Casas, FMG. ${ }^{\mathrm{a}, \mathrm{b}}$, Azevedo Júnior, SM. ${ }^{\mathrm{a}}$ and Dias Filho, MM. ${ }^{\mathrm{b}}$ \\ aPrograma de Pós-Graduação em Biologia Animal, Departamento de Zoologia, \\ Universidade Federal de Pernambuco - UFPE, Av. Professor Moraes Rego, 1235, \\ Cidade Universitária, CEP 50670-420, Recife, PE, Brazil \\ 'Programa de Pós-Graduação em Ecologia e Recursos Naturais, Departamento de Ecologia e Biologia Evolutiva, \\ Centro de Ciências Biológicas e da Saúde, Universidade Federal de São Carlos - UFSCar, \\ Rod. Washington Luiz, Km 235, CEP 13565-905, São Carlos, SP, Brazil \\ *e-mail: flormarialc@hotmail.com
}

Received November 16, 2010 - Accepted May 4, 2011 - Distributed February 29, 2012

\begin{abstract}
We studied hummingbirds and their food plants in an area of caatinga vegetation. We specifically examined their seasonal use of this habitat, migratory and non-migratory status, their foraging strategies and community roles The study was conducted in an area of arboreal-shrub caatinga, located in the Serra do Pará, municipality of Santa Cruz do Capibaribe, state of Pernambuco in northeastern Brazil. Field work was undertaken during 12 expeditions on a monthly basis between June, 2007 and May, 2008. Five species of hummingbirds were recorded visiting flowers in the community studied. Three were considered residents: Chlorostilbon lucidus (Shaw, 1812), Eupetomena macroura (Gmelin, 1788), and Heliomaster squamosus (Temminck, 1823). Hummingbirds visited 31 species of plants, of which only five presented attributes related to ornithophily. C. lucidus visited 29 plant species, including all ornithophilous species, and it was the most aggressive, defending territories. Among hummingbirds, $C$. lucidus may be considered the principal pollinator. Hummingbirds may also be acting as pollen vectors for some of the plant species not identified as ornithophilous. The hummingbird guilds varied among the plant species used as floral resources, as well as in their frequency of visits. Differences in plant species abundance, hummingbird preference, competitive exclusion or flowering seasonality are factors likely to influence those variations.
\end{abstract}

Keywords: caatinga, floral resources, hummingbirds, ornithophily, pollination.

\section{A comunidade de beija-flores (Aves: Trochilidae) e a assembleia de flores em uma área de Caatinga}

\begin{abstract}
Resumo
Propôs-se estudar os beija-flores e as espécies de plantas utilizadas como recurso alimentar em uma área de caatinga, estudando especificamente a sazonalidade das espécies de beija-flores nesse habitat, os status migratório e não migratório, as suas estratégias de forrageamento e os papéis comunitários. O estudo foi conduzido em uma área de caatinga arbóreo-arbustiva, localizada na Serra do Pará, município de Santa Cruz do Capibaribe, Estado de Pernambuco, no nordeste do Brasil. Os trabalhos de campo foram realizados durante 12 expedições mensais entre junho de 2007 e maio de 2008. Cinco espécies de beija-flores foram registradas visitando flores na comunidade estudada. Três espécies foram consideradas residentes: Chlorostilbon lucidus (Shaw, 1812), Eupetomena macroura (Gmelin, 1788) e Heliomaster squamosus (Temminck, 1823). Os beija-flores visitaram 31 espécies de plantas, das quais apenas cinco apresentaram atributos relacionados à ornitofilia. C. lucidus visitou 29 espécies de plantas, incluindo todas as ornitófilas, assim como também foi a espécie mais agressiva, defendendo territórios. Entre os beija-flores, $C$. lucidus pode ser considerado como o principal polinizador. Os beija-flores podem estar atuando como vetores de pólen para algumas espécies de plantas não identificadas como ornitófilas. As guildas de beija-flores variaram entre as espécies de plantas utilizadas como recurso floral, assim como nas suas frequências de visitas. Diferenças na abundância das espécies de plantas, na preferência por parte dos beija-flores, na exclusão competitiva ou na sazonalidade de floração são fatores que podem ter influência sobre essas variações.
\end{abstract}

Palavras-chave: caatinga, recursos florais, beija-flor, ornitofilia, polinização. 


\section{Introduction}

Birds play an important role in the reproduction of numerous plant species by either pollinating flowers or dispersing seeds (Snow, 1981). The most specialized birds feed on flower nectar and can act as effective pollinators (Faegri and van der Pijl, 1979; Stiles 1981). Hummingbirds are the most specialized avian nectarivores and are responsible for pollinating up to $15 \%$ of the angiosperms in the Neotropic (Stiles, 1981; Feinsinger, 1983; Bawa, 1990). Although some hummingbird species visit plants having a diversity of flower lengths and shapes (Feinsinger, 1976; Temeles et al., 2002) the specialization of plants determines variable degrees of affinity to bird-mediated pollination, different levels of specificity between plants and hummingbirds, and the guilds of hummingbird visitors (e.g., long- or short-billed; Snow and Snow, 1980).

The organization of hummingbird communities and the assemblage of flowers visited have been studied since the 1970's (e.g. Feinsinger, 1976, 1978; Brown and Kodrick-Brown, 1979; Stiles, 1978; Snow and Snow, 1980, 1986; Snow and Teixeira, 1982; Brown and Bowers, 1985; Arizmendi and Ornelas, 1990; Kreamer et al., 1993; Sazima et al., 1996; Cotton, 1998a,b,c; Buzato et al., 2000; Vasconcelos and Lombardi, 2000, 2001; Leal et al., 2006; Cotton, 2007; Machado et al., 2007; Dalsgaard, 2009; Machado, 2009; Abrahamczyk and Kessler, 2010). However, few studies have focused on both ornithophilous and nonornithophilous flower species used by hummingbirds, and were generally undertaken over a few days or months (e.g. Snow and Snow, 1980, 1986; Snow and Teixeira, 1982; Vasconcelos and Lombardi, 2001). In Brazil, most of the studies that have examined the relationships between birds and plants have focused on themes related to floral biology, pollination, and the reproduction of a given plant species or genus (Mendonça and Anjos 2003).

One Brazilian habitat that has received little study from the standpoint of hummingbird-plant communities is the caatinga dryland vegetation. Machado and Sazima (1995) studied the pollination biology of Ruellia asperula (Acanthaceae), Locatelli and Machado (1999) the floral biology of two ornithophilous species of Cactaceae, Machado and Lopes $(2003,2004)$ the occurrence and frequency of pollination systems in caatinga communities, Leal et al. (2006) the pollination of ornithophilous species and Machado (2009) the hummingbird community and their floral resources. Because this habitat contains a mixture of ornithophilous and especially non-ornithophilous plants, further studies of how hummingbirds use this environment are desirable.

Consequently, in an attempt to increase our understanding of the organization of hummingbird communities and the biotic interactions between them and their floral resources in habitats of dryland vegetation, we studied hummingbirds and their food plants in an area of caatinga vegetation in Pernambuco State, Brazil. We specifically examined their seasonal use of this habitat and migratory and non-migratory status, their foraging strategies, their community roles, and their plant food plants.

\section{Material and Methods}

This study was carried out in an area of arborealshrub caatinga vegetation in the Serra do Pará mountains, municipality of Santa Cruz do Capibaribe, Pernambuco State, Brazil (7 $7^{\circ} 2^{\prime} 29.20^{\prime \prime} \mathrm{S}$ and $\left.36^{\circ} 24^{\prime} 10.06^{\prime \prime} \mathrm{W}\right)$. This site is located in the Borborema Province, a landscape typical of the semi-arid region of northeastern Brazil (IBGE, 1992; Souza et al., 1994). The Serra do Pará mountains extend for $17 \mathrm{~km}$ at up to $729 \mathrm{~m}$ above sea level, within the states of Pernambuco and Paraíba. The regional climate is semiarid (Bs s'h' according to Köppen) with a very marked seasonal nature and with very low rainfall levels. Average annual temperatures vary between 23 and $27^{\circ} \mathrm{C}$. Rainfall is distributed irregularly during the year (from three to five months), with water deficits occurring during most of the year (Sampaio, 1995). The average annual rainfall in Santa Cruz do Capibaribe is $503.3 \mathrm{~mm}$, with a short rainy season (March to July) and a marked dry season (August to February) (SUDENE, 1990). During the study period, rainfall varied from $10.8 \mathrm{~mm}$ in December 2007 to $162.8 \mathrm{~mm}$ in March 2008.

Field work was undertaken between June 2007 and May 2008, with monthly five-day visits covering the morning and afternoon hours ( 30 hours/month), for a total of 334 hours of observation during the 12 months of the study. In March and May of 2008, weather conditions were very unfavorable and observations were made for only 8.5 and 25 hours in each month, respectively.

Hummingbirds were identified by direct observation with the naked eye or with the aid of $7 \times 35 \mathrm{~mm}$ binoculars and a field guide (Grantsau, 1988) when necessary. Behavioral observations were conducted using focal sampling (Altmann, 1974). The taxonomic classification system used was that of the "Comitê Brasileiro de Registros Ornitológicos" (CBRO, 2011).

For each species of plant visited, we recorded the species of hummingbird, the duration (in seconds) of the visit, and the number and frequency of their visits (n. of visits/total observation hours). Intra- and interspecific interactions between hummingbird species were also recorded. The foraging strategies and the community roles played by hummingbirds were defined according to Feinsinger and Colwell (1978). Body masses were obtained from Schuchmann (1999).

A floral visit was defined as the period in which a bird remained at a flower or inflorescence without perching to rest (Alves et al., 2000). The visitation frequency was calculated by dividing the total number of visits by each hummingbird species to each plant species by the total number of observation hours ( $\mathrm{n}=331$ hours) (Rojas and Ribon, 1997).

The frequency of occurence (FO) of hummingbirds was based on the number of days in which a given species was registered in relation to the total number of days in which the observations were conducted $(n=57)$. The width of the feeding niche of each hummingbird species, as measured by the number of different species of plants 
used as food resources was calculated using the Simpson Index (Margurran, 1988).

The plant species was identified by specialists and reference specimens were deposited in the UFP Geraldo Mariz Herbarium at the Universidade Federal de Pernambuco. The botanical nomenclature used for the plant species follows The International Plant Names Index (2010), while plant families followed the Angiosperm Phylogeny Group II (Souza and Lorenzi, 2008). Pollination syndromes (especially ornithophily) were identified according to specialists in the area and the technical literature (Faegri and van der Pijl, 1979; Conceição et al., 2007).

\section{Results}

Five species of hummingbirds were recorded in the study area as visitors to flowering plants: the Amethyst Woodstar, Calliphlox amethystina (Boddaert, 1783); the Glitteringbellied Emerald, Chlorostilbon lucidus (Shaw, 1812); the Ruby-topaz Hummingbird, Chrysolampis mosquitus (Linnaeus, 1758); the Swallow-tailed Hummingbird, Eupetomena macroura (Gmelin, 1788); and the Stripe-breasted Starthroat, Heliomaster squamosus (Temminck, 1823), all Trochilinae. A sixth species, the Broad-tipped Hermit Anopetia gounellei (Boucard, 1891), representative of the Phaethornithinae, was not observed visiting any of the flowers in the study area during the field work, but it was seen flying over the area at the end of the dry season.

Chlorostilbon lucidus, E. macroura, and H. squamosus were observed during all months of the study (Table 1). The first two species were observed most frequently $(\mathrm{FO}=100$ and $57.9 \%$, respectively), followed by $H$. squamosus with a FO of $47.4 \%$. Chrysolampis mosquitus was observed only during restricted periods of the year and $C$. amethystina was only observed in August 2007 (FO of 17.5 and 5.3\%, respectively).

Hummingbirds visited a total of 31 plant species distributed in 16 families (Table 2). In terms of taxonomic representation, the Cactaceae contributed the greatest number of species $(n=5)$, followed by Euphorbiaceae and Fabaceae with four species each, and Malvaceae with three species. The families Asteraceae, Bromeliaceae and Vitaceae were represented by two species each, and the nine remaining families, one species each.

Only five of these 31 plant species (16\%) had flowers showing characteristics associated with ornithophily: Ruellia asperula Lindau (Acanthaceae), Melocactus zehntneri (Britton \& Rose) Luetzelb., Tacinga inamoena (K. Schum.) N.P. Taylor \& Stuppy, Tacinga palmadora (Britton \& Rose) N.P. Taylor \& Stuppy (Cactaceae), and Hohenbergia cf. catingae Ule (Bromeliaceae). The other plant species all demonstrated characteristics associated with other pollination syndromes, especially entomophily.

Chlorostilbon lucidus was observed visiting 29 different plants, including all of the ornithophilous species, and was the sole hummingbird visitor to 14 plant species in the area, including the ornithophilous species Hohenbergia cf. catingae. In both numbers and frequency of visits, it was the major hummingbird pollinator in this caatinga community (Table 2).

Eupetomena macroura and $H$. squamosus each visited 11 species of plants. Eupetomena macroura visited three ornithophilous species and was the only hummingbird species observed visiting the flowers of an unidentified Pilosocereus species (Cactaceae). Heliomaster squamosus visited only a single ornithophilous species, T. palmadora, and was the only hummingbird seen visiting flowers of Croton blanchetianus Baill.. Chrysolampis mosquitus visited six plant species, one ornithophilous. Calliphlox amethystina was observed visiting only two plant species, $C$. halteris and T. palmadora (Table 2).

In terms of interactions among hummingbirds in the "Serra do Pará", C. lucidus, E. macroura and H. squamosus demonstrated territorial behavior, which included agonistic encounters. A total of 1,123 agonistic interactions were recorded, of which approximately $40 \%$ were interspecific (Table 3). Intraspecific aggression occurred with $C$. lucidus, E. macroura and H. squamosus. Chlorostilbon lucidus was recorded most frequently in territorial interactions ( $74 \%$ of

Table 1. Hummingbird seasonality at the Serra do Pará, Santa Cruz do Capibaribe, Pernambuco, between June 2007 and May 2008. Shaded columns correspond to the wet period and the white columns to the dry period.

\begin{tabular}{|c|c|c|c|c|c|c|c|c|c|c|c|c|}
\hline \multirow{2}{*}{ Sub-family/species } & \multicolumn{12}{|c|}{ Months } \\
\hline & June & July & Aug. & Sept. & Oct. & Nov. & Dec. & Jan. & Feb. & Mar. & Apr. & May \\
\hline \multicolumn{13}{|l|}{ Trochilinae } \\
\hline $\begin{array}{l}\text { Calliphlox amethystina } \\
\text { (Boddaert, 1783) }\end{array}$ & - & - & $\mathrm{x}$ & - & - & - & - & - & - & - & - & - \\
\hline $\begin{array}{l}\text { Chlorostilbon lucidus } \\
\text { (Shaw, 1812) }\end{array}$ & $\mathrm{x}$ & $\mathrm{x}$ & $\mathrm{x}$ & $\mathrm{x}$ & $\mathrm{x}$ & $\mathrm{x}$ & $\mathrm{x}$ & $\mathrm{x}$ & $\mathrm{x}$ & $\mathrm{x}$ & $\mathrm{x}$ & $\mathrm{x}$ \\
\hline $\begin{array}{l}\text { Chrysolampis mosquitus } \\
\text { (Linnaeus, 1758) }\end{array}$ & - & $\mathrm{x}$ & $\mathrm{x}$ & $\mathrm{x}$ & - & - & - & $\mathrm{x}$ & $\mathrm{x}$ & - & $\mathrm{x}$ & $\mathrm{x}$ \\
\hline $\begin{array}{l}\text { Eupetomena macroura } \\
\text { (Gmelin, 1788) }\end{array}$ & $\mathrm{x}$ & $\mathrm{x}$ & $\mathrm{x}$ & $\mathrm{x}$ & $\mathrm{x}$ & $\mathrm{x}$ & $\mathrm{x}$ & $\mathrm{x}$ & $\mathrm{x}$ & $\mathrm{x}$ & $\mathrm{x}$ & $\mathrm{x}$ \\
\hline $\begin{array}{l}\text { Heliomaster squamosus } \\
\text { (Temminck, 1823) }\end{array}$ & $\mathrm{x}$ & $\mathrm{x}$ & $\mathrm{x}$ & $\mathrm{x}$ & $\mathrm{x}$ & $\mathrm{x}$ & $\mathrm{x}$ & $\mathrm{x}$ & $\mathrm{x}$ & $\mathrm{x}$ & $\mathrm{x}$ & $\mathrm{x}$ \\
\hline
\end{tabular}


Table 2. Hummingbird visitation rates in the assemblage of flowers at the Serra do Pará, Santa Cruz do Capibaribe, Pernambuco, between June 2007 and May 2008.

\begin{tabular}{|c|c|c|c|c|c|c|c|c|c|c|c|c|c|c|c|}
\hline \multirow[t]{2}{*}{ Family/species } & \multicolumn{3}{|c|}{ Cl } & \multicolumn{3}{|c|}{ Em } & \multicolumn{3}{|c|}{ Hs } & \multicolumn{3}{|c|}{$\mathbf{C m}$} & \multicolumn{3}{|c|}{$\mathbf{C a}$} \\
\hline & NV & MT & FV & NV & MT & FV & NV & MT & FV & NV & MT & FV & NV & MT & FV \\
\hline \multicolumn{16}{|l|}{ ACANTHACEAE } \\
\hline Ruellia asperula* & 18 & 8.1 & 0.05 & - & - & - & - & - & - & - & - & - & - & - & - \\
\hline \multicolumn{16}{|l|}{ APOCYNACEAE } \\
\hline Allamanda blanchetii & 6 & 7.2 & 0.02 & - & - & - & 1 & 1 & 0.003 & - & - & - & - & - & - \\
\hline \multicolumn{16}{|l|}{ ASTERACEAE } \\
\hline Conocliniopsis prasiifolia & 3 & 2,3 & 0.009 & - & - & - & - & - & - & - & - & - & - & - & - \\
\hline Pithecoseris pacourinoides & 5 & 9.6 & 0.01 & - & - & - & - & - & - & - & - & - & - & - & - \\
\hline \multicolumn{16}{|l|}{ BIGNONIACEAE } \\
\hline Tabebuia impetiginosa & 208 & 12.3 & 0.62 & 32 & 11.8 & 0.09 & 97 & 10.8 & 0.29 & 18 & 7.8 & 0.05 & - & - & - \\
\hline \multicolumn{16}{|l|}{ BROMELIACEAE } \\
\hline Encholirium spectabile & 53 & 9.3 & 0.15 & 16 & 3.9 & 0.04 & 11 & 9,5 & 0,03 & - & - & - & - & - & - \\
\hline Hohenbergia cf catingae* & 318 & 9.4 & 0.96 & - & - & - & - & - & - & - & - & - & - & - & - \\
\hline \multicolumn{16}{|l|}{ CACTACEAE } \\
\hline Melocactus zehntneri* & 871 & 2.8 & 2.60 & 14 & 3.1 & 0.04 & - & - & - & - & - & - & - & - & - \\
\hline Pilosocereus sp. & - & - & - & 4 & 9.3 & 0.01 & - & - & - & - & - & - & - & - & - \\
\hline Pilosocereus gounellei & 1 & 2 & 0.003 & - & - & - & - & - & - & - & - & - & - & - & - \\
\hline Tacinga palmadora* & 1524 & 4.3 & 4.56 & 3 & 2 & 0.009 & 48 & 4.9 & 0.14 & 1 & 2 & 0.003 & 1 & 2 & 0.003 \\
\hline Tacinga inamoena* & 19 & 6.2 & 0.05 & 2 & 1.5 & 0.006 & - & - & - & - & - & - & - & - & - \\
\hline \multicolumn{16}{|l|}{ CONVOLVULACEAE } \\
\hline Ipomoea $\mathrm{sp}$ & 18 & 4.4 & 0.05 & - & - & - & 4 & 3.7 & 0.01 & - & - & - & - & - & - \\
\hline \multicolumn{16}{|l|}{ EUPHORBIACEAE } \\
\hline Cnidoscolus halteris & 6269 & 7.1 & 18.7 & 1242 & 6.1 & 3.71 & 416 & 4.8 & 1.24 & 46 & 8.9 & 0.13 & 66 & 0.6 & 0.19 \\
\hline Cnidoscolus obtusifolius & 210 & 9.3 & 0.62 & - & - & - & - & - & - & - & - & - & - & - & - \\
\hline Jatropha mollissima & 80 & 3.9 & 0.23 & 1 & 2 & 0.003 & - & - & - & 2 & 1.5 & 0.006 & - & - & - \\
\hline Croton blanchetianus & - & - & - & - & - & - & 1 & 1 & 0.003 & - & - & - & - & - & - \\
\hline \multicolumn{16}{|l|}{ FABACEAE } \\
\hline Bauhinia cheilantha & 92 & 7.7 & 0.27 & 14 & 5.4 & 0.04 & 6 & 5.2 & 0.02 & 2 & 2.5 & 0.006 & - & - & - \\
\hline Caesalpinia pyramidalis & 1 & 2 & 0.003 & - & - & - & - & - & - & - & - & - & - & - & - \\
\hline Dioclea grandiflora & 1 & 7 & 0.003 & - & - & - & 1 & 12 & 0.003 & - & - & - & - & - & - \\
\hline Anadenanthera macrocarpa & 1 & 4 & 0.003 & - & - & - & - & - & - & - & - & - & - & - & - \\
\hline \multicolumn{16}{|l|}{ LAMIACEAE } \\
\hline Hyptis pectinata & 2 & 2.0 & 0.006 & - & - & - & - & - & - & - & - & - & - & - & - \\
\hline \multicolumn{16}{|l|}{ MALVACEAE } \\
\hline Ceiba glaziovii & 1 & 14.0 & 0.003 & - & - & - & 2 & 2,5 & 0.006 & - & - & - & - & - & - \\
\hline Melochia tomentosa & 581 & 4.4 & 1.73 & 2 & 4.5 & 0.006 & 1 & 2 & 0.003 & 4 & 2 & 0.01 & - & - & - \\
\hline Walteria rotundifolia & 1 & 2 & 0.003 & - & - & - & - & - & - & - & - & - & - & - & - \\
\hline MYRTACEAE & & & & & & & & & & & & & & & \\
\hline Psidium sp. & 1 & 17.0 & 0.003 & - & - & - & - & - & - & - & - & - & - & - & - \\
\hline OXALIDACEAE & & & & & & & & & & & & & & & \\
\hline Oxalis psoraleoides & 937 & 3.2 & 2.80 & - & - & - & - & - & - & - & - & - & - & - & - \\
\hline PLUMBAGINACEAE & & & & & & & & & & & & & & & \\
\hline Plumbago scandens & 95 & 3.0 & 0.28 & 1 & 3 & 0.003 & - & - & - & - & - & - & - & - & - \\
\hline RUBIACEAE & & & & & & & & & & & & & & & \\
\hline Staelia galioides & 1 & 2.0 & 0.003 & - & - & - & - & - & - & - & - & - & - & - & - \\
\hline VITACEAE & & & & & & & & & & & & & & & \\
\hline Cissus simsiana & 203 & 8.1 & 0.60 & - & - & - & - & - & - & - & - & - & - & - & - \\
\hline Cissus verticillata & 5 & 22.4 & 0.01 & - & - & - & - & - & - & - & - & - & - & - & - \\
\hline
\end{tabular}

$\mathrm{NV}$ : number of visits, MT: mean visit time and FV: frequency of visit. $\mathrm{Cl}=$ Chlorostilbon lucidus, Em = Eupetomena macroura, $\mathrm{Hs}=$ Heliomaster squamosus, $\mathrm{Cm}=$ Chrysolampis mosquitus and $\mathrm{Ca}=$ Calliphlox amethystina . Species with an asterisk are ornithophilous. 
Table 3. Aggressive encounters among hummingbirds at the Serra do Pará, Santa Cruz do Capibaribe, Pernambuco, between June 2007 and May 2008.

\begin{tabular}{lccccc}
\hline \multicolumn{1}{c}{ Dominant } & \multicolumn{5}{c}{ Subordinate species } \\
\cline { 2 - 6 } \multicolumn{1}{c}{ species } & C. lucidus & E. macroura & H. squamosus & C. mosquitus & C. amethystina \\
\hline C. lucidus & 629 & 111 & 77 & 11 & 3 \\
E. macroura & 214 & 35 & 9 & 1 & 1 \\
H. squamosus & 9 & 0 & 20 & 0 & 0 \\
C. mosquitus & 3 & 0 & 0 & 0 & 0 \\
C. amethystina & 0 & 0 & 0 & 0 & 0 \\
\hline
\end{tabular}

the total agonistic encounters, with $40.5 \%$ involving other species; see Table 3). This hummingbird was observed expelling Lepidoptera, Hymenoptera and considerably larger birds such as Coereba flaveola (Linnaeus, 1758), Cyanoloxia brissonii (Lichtenstein, 1823) and Falco femoralis Temminck, 1822.

The hummingbird species with the widest feeding niche was $C$. lucidus (Bij = 3.33), followed by C. mosquitus (Bij = 2.85), H. squamosus $(\mathrm{Bij}=2.62)$, E. macroura $(\mathrm{Bij}=1.35)$ and $C$. amethystina $(\mathrm{Bij}=1.15)$.

\section{Discussion}

\subsection{The hummingbird community}

The hummingbird guild in the Serra do Pará is speciespoor when compared to other Neotropical sites (Arizmendi and Ornelas, 1990; Dziedzioch et al., 2003; Abrahamczyk and Kessler, 2010). Most of the species in the guild are generalists in terms of habitat use, with a wide distribution in Brazil and other countries in South America; the one exception is $H$. squamosus, which is restricted to eastern Brazil (Sick, 1997; Rodriguez-Mata et al., 2006). However, the guild composition is similar to the guilds observed by Leal et al. (2006), Dalsgaard et al. (2009) and Machado (2009). The five hummingbird species found in the guild represent approximately $18 \%$ of the total number of Trochilidae species recorded for the entire caatinga vegetations (Silva et al., 2003). The strong seasonality found in this region, characterized by a marked dry season, allied with the isolated physiognomy of the Serra do Pará, surrounded by altered and modified areas of vegetation, are factors likely limiting the hummingbird species richness in the region.

The occurrence of C. lucidus, E. macroura and $H$. squamosus in the area during the entire year of study, as well as observations of nesting by the first two species and the presence of juveniles of the latter species, indicates that they are residents. The prolonged flowering period of certain floral resources, principally in areas with accentuated seasonal variations such as the caatingas dryland vegetations, and the asynchronous flowering of different resources with varied floral attributes, ensure a continuous yearly resource base that is fundamental in maintaining hummingbird communities (Feinsinger, 1978; Locatelli and Machado, 1999) as observed in the studied area.
Chrysolampis mosquitus and C. amethystina were considered non-residents as they were only occasionally observed in the study area. According to Sick (1997), C. mosquitus migrates in relation to seasons, with a north-south route in Brazil. Calliphlox amethystina is designated as locally migratory in some locations and periods (Sigrist, 2006). According to Morrison (1984), migration is characterized by cyclic and seasonal displacements, associated with feeding and reproductive factors necessary to the life cycle of species. Hummingbird migrations, especially in the Neotropics, have received little attention, and we suggest that the disappearance of certain species from the study area reflects displacements to areas richer in floral resources during periods of scarcity, especially for those species that cannot successfully compete for feeding territories (e.g. Buzato et al., 2000 and Machado et al., 2007).

Lastly, the only Phaethornithinae (hermit) species registered was A. gounellei, a caatinga endemic (Sick, 1997). This species occurs preferably in forested ecosystems (Silva et al., 2003) and was presumed to be resident in an area of arboreal caatinga vegetation in the "Chapada Diamantina", state of Bahia, Brazil (Machado, 2009). The number of hermit species is low when compared to other Neotropical regions, although Vasconcelos and Lombardi (2001), Leal et al. (2006), Machado et al. (2007) and Machado (2009) found similar species richness for this subfamily in their studies of caatinga and campos rupestres vegetations. The observation of a single species of this subfamily may indicate that the community studied may not support a considerable diversity of Phaethornithinae once there is a scarcity of flowers with floral characteristics associated with these taxa. Only $16 \%$ of the plant community presented ornithophilous traits, and species within the Phaethornithinae have a close coevolutionary association with ornithophilous plants (Stiles, 1975; Schuchmann, 1999).

\subsection{The plant community}

We recorded hummingbirds as visitors to 31 species of plants, a total similar to that observed in other opened and forested sites (e.g. Buzato et al., 2000; Machado et al., 2007; Machado, 2009; Abrahamczyk and Kessler, 2010). The Cactaceae were the most abundant food plant taxon in this community (Table 2). Leal et al. (2006) also noted a large representation of Cactaceae species visited by hummingbirds in another area of shrub-arboreal caatinga vegetation in Pernambuco State. As in our study, Euphorbiaceae, Fabaceae and Asteraceae are 
cited by other authors as important floral resources for hummingbirds (e.g. Araújo and Sazima, 2003; Leal et al., 2006; Machado et al., 2007; Machado, 2009). The plant families visited in different ecosystems (e.g., dry or wet forest) might be largely explained by the fact that these families are among the most frequent in those areas. The importance of the family Cactaceae as a floral resource for hummingbirds in the caatinga vegetations is noteworthy because it is one of the most representative families with ornithophilous species in this phythogeographic province, as well as in different regions with dry forest vegetations (Gentry, 1995; Machado and Lopes, 2003, 2004).

Most of the plants visited by hummingbirds were associated with non-ornithophilous pollination syndromes. Similar results have been found in other study sites and ecosystems (e.g. Vasconcelos and Lombardi, 2001; Machado et al., 2007; Machado, 2009). As suggested by Araújo and Sazima (2003) and Leal et al. (2006), the high frequency of non-ornithophilous plant species visited by hummingbirds may be explained by the low occurrence of ornithophilous species in the area. These non-ornithophilous plants may represent an important energy source that permits the establishment of permanent hummingbird communities in climatically rigorous ecosystems such as the caatinga, especially during the rainy season, when most ornithophilous species are not flowering (e.g. Machado and Lopes, 2003, 2004; Leal et al., 2006). At our study site, some hummingbird species may also act as pollinators for some non-ornithophilous species such as $C$. halteris and Cnidoscolus obtusifolius Pohl. (Euphorbiaceae) since they were observed making legitimate visits to flowers of these plants by contacting their reproductive structures, and also were observed with pollen on their bills.

Among all of the plant species identified in the present survey, the non-ornithophilous $C$. halteris (Euphorbiaceae) was the most visited. This plant species was also visited by other animals such as Lepidoptera, Hymenoptera (Xylocopa sp., and Apis mellifera), and birds C. flaveola and Aratinga cactorum (Kuhl, 1820). The ornithophilous T. palmadora (Cactaceae) was the second plant most visited by $C$. lucidus, while the non-ornithophilous T. impetiginosa (Bignonicaceae) was the second plant most visited by C. mosquitus, E. macroura and H. squamosus. These high rates of visitation may be explained by the fact that some plant species are more abundant, or have more flowers than others in the studied area. On the other hand, some hummingbird species may present low frequencies of visitation rates due to competitive exclusion, resulting in a high frequency of visit to those resources by territorial hummingbirds. Nectar competition in coexisting nectarivorous birds, expressed in aggressive behavior and territory defense, is conspicuous, affecting patterns of flower choice, daily behavior budgets and preventing or reducing access of a competitor, thus influencing visitation rates (Gill, 1978).

\subsection{The hummingbird guild}

In our study, data obtained from a feeding niche width suggest that hummingbirds differ in the extension of different flowers used as floral resources. Chlorostilbon lucidus demonstrated the widest feeding niche, and at other sites visited additional plant species, including non-ornithophilous species (Leal et al., 2006; Machado et al., 2007). According to Alves et al. (2000), the niche amplitude of this species may result from the more generalized morphology and size of their beaks, which permits the use of flowers of various shapes and sizes. More data are needed to better examine this hypothesis.

This species visited the greatest number of ornithophilous species, as well as a great array of different types of nonornithophilous plant species. Because of these factors and due to its site fidelity and the fact that it visited legitimately the greatest number of ornithophilous plants, it was considered the principal pollinator and the organizing species in the community studied (sensu Feinsinger and Colwell, 1978). The remaining resident species were considered secondary pollinators.

Eupetomena macroura and C. lucidus were observed actively defending territories of $C$. halteris (Euphorbiaceae); Heliomaster squamosus, C. lucidus, C. mosquitus and E. macroura of T. impetiginosa flowers, indicating that these hummingbird species are co-dominant (Stiles and Wolf, 1970). Chlorostilbon lucidus and E. macroura were also observed to be involved in most of the agonistic encounters noted in the present study. When evaluating the dominance hierarchy, subordinations during aggressive encounters, and hummingbirds' body mass, we can observe that the largest species dominated the smallest ones. This suggests that dominance in this hummingbird community depends in part on body size (Brown et al., 1978), and in part on foraging strategies, since some hummingbirds are trapliners. With the exception of C. lucidus, in general, the other hummingbird species made traplining or occasional visits.

The results of the present study indicate that the hummingbird guilds vary among plant species, with some of the hummingbird species visiting a broad array of plant species. Nevertheless, our data show certain differences in hummingbirds' visitation rates among the different species of plants.

The hummingbird community seems to present different mechanisms of resource utilisation, reflected in the evolution of foraging behavior, which is influenced by interactions with other hummingbird species, floral morphology and flowering phenology; as well as in differences in the ability to explore distinct plant species which is determined by hummingbird morphological traits (e.g., culmen (bill) length, body mass, length and aeordynamics of the wing; Feinsinger, 1976; Feinsinger and Colwell, 1978; Brown and Bowers, 1985).

Differences in visitation rates may be explained by the relative abundance of plant species, since birds may visit plants in proportion to their relative abundance, as we suggested. Bird preference may be a second explanation, since some hummingbirds may visit some plants more than others because they prefer those plants. A third explanation may be related to competitive exclusion, by territoriality and aggressive behavior. Some hummingbirds may exclude others via aggression, resulting in different patterns of visits between hummingbird species. Seasonality 
may be another factor, since it influences the flowering of species, and species abundance (E. Temeles, pers. comm.). Lastly, nectar productivity and concentrations may have an influence on the number of plant species visited by different hummingbirds or on the time spent on the same individual (Melo, 2001). Nevertheless, further data on the relative abundance of plant and hummingbird species are required to test those hypotheses.

Studies concerning ecomorphology between hummingbirds and food plants are also indicated in order to better understand patterns of hummingbird-plant interactions in the organization of the hummingbird-plant community in this unique Brazilian habitat, the caatinga dryland vegetation.

Acknowledgements - The authors are grateful to CAPES for the financial support of FMG Las-Casas during her Master's degree; M Barbosa (UFP Herbarium) for orientation in processing the botanical material; EMN Ferraz (CEFET/PE), AL Melo (UAST/ UFRPE), IC Machado (UFPE), JA Siqueira Filho (UNIVASF), MRCS de Melo (UFRPE), and R Pereira (IPA/PE) in plant identification; We are very grateful to Prof Ethan J. Temeles for the valuable comments, discussions and suggestions on this manuscript as well as in the English revision, and we would also like to thank the anonymous reviewer for the useful comments.

\section{References}

ABRAHAMCZYK, S. and KESSLER, M., 2010. Hummingbird diversity, food niche characters, and assemblage composition along a latitudinal precipitation gradient in the Bolivian lowlands. Journal of Ornithology, vol. 151, p. 615-625. http://dx.doi. org/10.1007/s10336-010-0496-x

ALTMANN, SA., 1974. Observational study behavior: sampling methods. Behavior, vol. 49, p. 227-265.

ALVES, MAS., ROCHA, CFD., SLUYS, MV. and BERGALLO, HG., 2000. Guildas de beija-flores polinizadores de quatro espécies de Bromeliaceae de Mata Atlântica da Ilha Grande, RJ, Brasil: Composição e Taxas de Visitação. In ALVES, MAS., SILVA, JMC., VAN SLUYS, M., BERGALLO, HG. and ROCHA, CFD. (Orgs.). A ornitologia no Brasil: desenvolvimento, tendências atuais e perspectivas. Rio de Janeiro: Editora Universidade Estadual do Rio de Janeiro. p. 171-183.

ARAÚJO, AC. and SAZIMA, M., 2003. The assemblage of flowers visited by hummingbirds in the "capões" of southern Pantanal, Mato Grosso do Sul, Brazil. Flora, vol. 198, p. 1-9.

ARIZMENDI, MC. and ORNELAS, JF., 1990. Hummingbirds and their floral resources in a tropical dry Forest in Mexico. Biotropica, vol. 22, p. 172-180. http://dx.doi.org/10.2307/2388410

BAWA, KS., 1990. Plant-pollinator interactions in a tropical rain forest. Annual Review of Ecology, Evolution and Systematics, vol. 21, p. 339-422.

BROWN, JH. and BOWERS, MA., 1985. Community organization in hummingbirds: relationships between morphology and ecology. The Auk, vol. 102, no. 2, p. 251-269.

BROWN, JH., CALDER, WA. and KODRICK-BROWN, A., 1978. Correlates and consequences of body size in nectar-feeding birds. American Zoologist, vol. 18, no. 4, p. 687-378.

BROWN, JH. and KODRICK-BROWN, A., 1979. Convergence, competition, and mimicry in a temperate community of hummingbird pollinated flowers. Ecology, vol. 60, no. 5, p. 1022-1035. http:// dx.doi.org/10.2307/1936870
BUZATO, S., SAZIMA, M. and SAZIMA, I., 2000. Hummingbirdpollinated floras at three Atlantic Forest sites. Biotropica, vol. 32, p. $824-841$.

Comitê Brasileiro de Registros Ornitológicos - CBRO, 2011. Lista das Aves do Brasil. Available from: <http://cbro.org.br>. Access in: 14 fev. 2011.

CONCEIÇÃO, AA., FUNCH, LS. and PIRANI, JR. 2007. Reproductive phenology, pollination and seed dispersal syndromes on sandstone outcrop vegetation in the "Chapada Diamantina", northeastern Brazil: population and community analyses. Revista Brasileira de Botânica, vol. 30, no. 3, p. 475-485.

COTTON, PA., 1998a. Coevolution in an Amazonian hummingbirdplant community. Ibis, vol. 140, p. 639-646.

-, 1998b. The community organization of a lowland Amazonian forest. Ibis, vol. 140, p. 512-521.

-, 1998c. Temporal partitioning of a floral resource by territorial hummingibrds. Ibis, vol. 140, p. 647-653.

-, 2007. Seasonal resource tracking by Amazonian hummingbirds. Ibis, vol. 149, p. 135-142.

DALSGAARD, B., MARTÍN GONZÁLEZ, AM., OLESEN, JM., TIMMERMANN, A., ANDERSEN, LH. and TOSSAS, AG., 2009. Plant-hummingbird interactions in the West Indies: floral specialization gradients associated with environment and hummingbird size. Oecologia, vol. 159, p. 757-766. PMid:19132403. http://dx.doi.org/10.1007/s00442-008-1255-Z

DZIEDZIOCH, C., STEVENS, A-D. and GOTTSBERGER, G., 2003. The hummingbird-plant community of a tropical montane rain forest in southern Ecuador. Plant Biology, vol. 5, p. 331-337. http://dx.doi.org/10.1055/s-2003-40802

FAEGRI, K. and VAN DER PIJL, L., 1979. The principles of pollination ecology. Oxford: Pergamon Press. 244 p.

FEINSINGER, P., 1976. Organization of a tropical guild of nectarivorous birds. Ecological Monographs, vol. 46, p. 257-291. http://dx.doi.org/10.2307/1942255

-, 1978. Ecological interactions between plants and hummingbirds in a successional tropical community. Ecological Monographs, vol. 48, p. 269-287. http://dx.doi.org/10.2307/2937231

-, 1983. Coevolution and pollination. In FUTUYMA, D. and SLATKIN, M. (Eds.). Coevolution. Sunderland: Sinauer Associates Publishers. p. 283-310.

FEINSINGER, P. and COLWELL, RK., 1978. Community organization among neotropical nectar-feeding birds. American Zoology, vol. 18, p. 779-795.

GRANTSAU, R., 1988. Os beija-flores do Brasil. Rio de janeiro: Ed. Expressão e Cultura. 232 p.

GENTRY, A., 1995. Diversity and floristic composition of Neotropical dry forests. In BULLOCK, H., MONEY, A. and MEDINA, E. (Eds.). Seasonally dry tropical forest. Cambridge: Cambridge University Press. p.146-194.

GILL, FB., 1978. Proximate Costs of Competition for nectar. American Zoology, vol. 18, p. 753-763.

Instituto Brasileiro de Geografia e Estatística - IBGE, 1992. Manual Técnico da Vegetação Brasileira. Rio de Janeiro: IBGE. Série Manuais Técnicos em Geociências, no. 1.

KREAMER, M., SCHMITT, U. and SCHUCHMANN, KL., 1993. Notes on the organization of a Neotropical high-altitude hummingbird flower community. In BARTHLOTT, W., NAUMANN, CM., SCHMIDT-LOSKE, L. and SCHUCHMANN, KL. (Eds.). Animal- 
plant interactions in tropical environments. Bonn. p. 61-65. Results of Annual Meeting of the German Society for Tropical Ecology.

LEAL, FC., LOPES, AV. and MACHADO, IC., 2006. Polinização por beija-flores em uma área de Caatinga no Município de Floresta, Pernambuco, Nordeste do Brasil. Revista Brasileira de Botânica, vol. 29 , no. 3 , p. 379-389.

LOCATELLI, E. and MACHADO, IC., 1999. Comparative study of the floral biology of two ornithophilous species of Cactaceae: Melocactus zehntneri and Opuntia palmadora. Bradleya, vol. 17, p. $75-85$

MACHADO, CG., 2009. Beija-flores (Aves: Trochilidae) e seus recursos florais em uma área de caatinga da Chapada Diamantina, Bahia, Brasil. Zoologia, vol. 26, no. 2, p. 255-265.

MACHADO, CG., COELHO, AG., SANTANA, CS. and RODRIGUES, M., 2007. Beija-flores e seus recursos florais em uma área de campo rupestre da Chapada Diamantina, Bahia. Revista Brasileira de Ornitologia, vol. 15, no. 2, p. 267-279.

MACHADO, ICS. and LOPES, AV., 2003. Recursos florais e sistemas de polinização e sexuais em Caatinga. In LEAL, IR., TABARELLI, M. and SILVA, JMC. (Orgs.). Ecologia e Conservação da Caatinga. Recife: Editora UFPE. p. 515-563.

-, 2004. Floral traits and pollination systems in the caatinga, a Brazilian tropical dry forest. Annals of Botany, vol. 94, p. 365376. PMid:15286010. http://dx.doi.org/10.1093/aob/mch152

MACHADO, ICS. and SAZIMA, M., 1995. Biologia da polinização e pilhagem por beija-flores em Ruellia asperula Lindau (Acanthaceae) na caatinga, Nordeste Brasileiro. Revista Brasileira de Botânica, vol. 18 , p. 27-33.

MARGURRAN, AE., 1988. Ecological diversity and its measurement. Sydney: Croom Helm.

MELO, C., 2001. Diurnal bird visiting of Caryocar brasiliense Camb. In Central Brazil. Revista Brasileira de Biologia, vol. 61, no. 2 , p. $311-316$.

MENDONÇA, LB. and ANJOS, L., 2003. Bird flower interactions In Brazil: a review. Ararajuba, vol. 11, no. 2, p. 195-202.

MORRISON, RG., 1984. Migration systems of some new world shorebirds, p. 125-202. In BURGER, J. and OLLA, EBL. (Eds.). Behavior of marine animals. New York: Plenum Press. Shorebirds: migration and foraging behavior, vol. 6 .

RODRIGUEZ-MATA, JR., ERIZE, F. and RUMBOLL, M., 2006. Collins Filed Guide. Birds - South America. Non-passerines: from rheas to woodpeckers. London: Harper Collins Publishers Ltd. Hammersmith.

ROJAS, R., and RIBON, R., 1997. Guilda de aves em Bowdichia virgilioides (Fabaceae: Faboidae) em área de cerrado de Furnas, Minas Gerais. Ararajuba, vol. 5, no. 2, p. 189-194.

SAMPAIO, EVS., 1995. Overview of the Brazilian Caatinga. In BULLOCK, SH., MOONEY, HA. and MEDINA, E. (Eds.). Seasonally dry tropical forests. Cambridge: Cambridge University Press. p. 35-63.

SAZIMA, I., BUZATO, S. and SAZIMA, M., 1996. An assemblage of hummingbird-pollinated flowers in a montane forest in southeastern. Acta Botanica Brasilica, vol. 109, p. 81-176.

SCHUCHMANN, KL., 1999. Family Trochilidae (Hummingbirds). In DEL HOYO, J., ELLIOTT, A. and SARGATAL, J. (Eds.). Handbook of the Birds of the World. Barcelona: Lynx Edicions. vol. 5.

SICK, H., 1997. Ornitologia Brasileira. Rio de Janeiro: Nova Fronteira. 912 p.
SIGRIST, T. 2006. Aves do Brasil: uma visão artística. São Paulo: Editora Avis Brasilis. 672 p.

SILVA, JMC., SOUZA, MA., DIEBER, AGD. and CARLOS, CJ., 2003. Aves da caatinga: Status, uso do hábitat e sensitividade. In LEAL, IR., TABARELLI, M. and SILVA, JMC. (Orgs.). Ecologia $e$ Conservação da Caatinga. Recife: Editora UFPE. p. 262-263.

SNOW, BK., 1981. Relationships between hermit hummingbirds and their food plants in eastern Ecuador. Bulletin of the British Ornithologists'Club, vol. 101, p. 387-396.

SNOW, DW. and SNOW, BK., 1980. Relationships between hummingbirds and flowers in Andes of Colombia. Bulletin of the Museum of Natural History (Zoology), vol. 38, p. 105-139.

,- 1986 . Feeding ecology of hummingbirds in the Serra do Mar, southeastern Brazil. El Hornero, vol. 12, p. 286-296.

SNOW, DW. and TEIXEIRA, DL., 1982. Hummingbirds and their flowers in the coastal mountains of southeastern Brazil. Journal für Ornithology, vol. 123, p. 446-450.

SOUZA, VC. and LORENZI, H., 2008. Botânica Sistemática: guia ilustrado para identificação das famílias de Angiospermas da flora brasileira em APG II. 2nd ed. Nova Odessa: Instituto Plantarum.

SOUZA, MJN., MARTINS, MLR., SOARES, ZML., FREITASFILHO, MR., ALMEIDA, MAG., PINHEIRO, FSA., SAMPAIO, MAB., CARVALHO, GMBS., SOARES, AML., GOMES, ECB. and SILVA, RA., 1994. Redimensionamento da região semi-árida do Nordeste do Brasil. In Fundação Cearense de Meteorologia e Recursos Hídricos - FUNCEME (Orgs.). Conferência Nacional e Seminário Latino-Americano de Desertificação. Fortaleza: Fundação Esquel do Brasil. p. 1-34.

STILES, FG., 1975. Ecology, flowering phenology, and hummingbird pollination of some Costa Rican Heliconia species. Ecology, vol. 56, p. 285-301. http://dx.doi.org/10.2307/1934961

-, 1978. Temporal organization of flowering among the hummingbird foodplants of a tropical wet forest. Biotropica, vol. 10, no. 3, p. 194-210. http://dx.doi.org/10.2307/2387905

-, 1981. Geographical aspects of Bird-flower coevolution, with particular reference to Central America. Annals of the Missouri Botanical Garden, vol. 68, p. 323-351. http://dx.doi. org/10.2307/2398801

-, 1995. Behavioral, ecological and morphological correlates of foraging for arthropods by hummingbirds of a tropical wet Forest. The Condor, vol. 97, p. 853-878. http://dx.doi.org/10.2307/1369527

STILES, FG. and WOLF, LL., 1970. Hummingbird territoriality at a tropical flowering tree. The Auk, vol. 87, p. 467-491.

Superintendência do Desenvolvimento do Nordeste - SUDENE, 1990. Dados pluviométricos do Nordeste - Estado de Pernambuco. Recife: Superintendência do Desenvolvimento do Nordeste. Série Pluviométrica 6.

TEMELES, EJ., LINHART, YB., MASONJONES, M., and MASONJONES, HD. 2002. The role of flower width in hummingbird bill lenght - flower lenght relationships. Biotropica vol. 34, p. 68-80.

The International Plant Names Index. 2010. Available from: $<$ http://www.ipni.org >. Acessed 04 nov. 2010.

VASCONCELOS, MF. and LOMBARDI, JA., 2000. Espécies vegetais visitadas por beija-flores no meio do verão no Parque Estadual da Pedra Azul, Espírito Santo. Melopsitaccus, vol. 3, no. 1 , p. 36-41.

-, 2001. Hummingbirds and their flowers in the campos rupestres of southern Espinhaço Range, Brazil. Melopsitaccus, vol. 4, p. 3-30. 